\title{
SOCIAL ECONOMY: INCLUSION OF PERSON AND HUMAN SOCIABILITY
}

\author{
UDC: 316.334 .2 \\ 316.4:330.1 \\ Review Scientific Paper
}

\begin{abstract}
Maša MAGZAN
Zagreb School of Economics and Management, 10000 Zagreb, Jordanovac 110, Republic of Croatia E-mail: masa.magzan@zsem.hr
\end{abstract}

Paper received: 15.05.2013.; Paper accepted: 17.11.2013.

\begin{abstract}
The paper focuses on the social economy as an engine for development because of its principles on reciprocity and cooperation are meeting the needs that are not adequately addressed by neither the public nor private economy. Since the contemporary economic theory considers these forms of economic activity as something marginal, there is a growing need for more knowledge about the cooperative model as a business form, both in terms of its unique leadership and management structure, as well as the application of co-operative practice to a wide variety of activities. The goal of the paper is to present the principles of social economy in order to challenge current political and economic policies who still fail to provide minimum acceptable levels of economic and social well being to growing numbers of people. The ultimate goal of the paper is to emphasize the liberating potential of an anthropologically informed economics where social relations and human concerns are placed at the centre of economics. The paper's scope is by no means exhaustive, and primarily focuses on encouraging further interdisciplinary studies and participation of scholars from diverse fields, such as business management, sociology, political science, and economics in this respect.
\end{abstract}

Key words: social economy, civil economy, relational anthropology, social dimension of economic behavior, social economy organizations.

\section{INTRODUCTION}

Over the course of the last two centuries, there has been an ongoing debate how to relate the practice of economics and the development of economic institutions to the question of social benefit. This struggle continues today, and it is especially meaningful in the context of global crisis and the need to transform the unjust economic structures and move away from the isolated creation of market values and recognize social and ecological values. The predominant view of economic behaviour is still separated from the broader social and psychological conditions that explain human behaviour.

Within the realm of traditional economics, narcissistic vision of the homo oeconomicus has failed to acknowledge long-documented evidence of the primacy of cooperation. Although the contemporary economic theory still considers cooperation as something marginal or even esoteric, in the context of current economic crisis, the principles of social economy deserve our attention because they contribute to building a world that is more fair and just. By seing human beings not as self-interested individuals, but 'giftexchanging animals' who are naturally disposed to cooperate for mutual benefit, social economy establishes the link between economy and society and enables promotion of welfare for workers and consumers, environmental protection and sustainable development.

The failure of mainstream economics to address these issues is a key reason for the increasing interest in finding new strategies and paradigms that are more just, equitable, and responsive to the broader needs of society. Emphasizing mutual and collective benefit and being animated on the priciple of reciprocity, the social economy represents a response to this disconnected, and by 
some, even anti social view because unlike public and private sector economies, social economists are working towards the reinsertion of social goals, reciprocity and solidarity into economic thinking and decision making.

There is a wide range of different types of social enterprises with the common purpose which is to address specific social goals through the conduct of commercial business. Various non profits, trade and credit unions, business associations, cooperatives, cultural and religious organizations, as well as recreational groups function having different types of values, goals and structures. But what they all have incommon is the promotion of mutual and collective benefit and the building of community that results from the operation of reciprocity either at the economic or social level. Establishing the link between society and economy, local and global, labour and investment, as well as production, consumption and the environment, the social economy is discussed here as an engine for development because of its important role in meeting the needs that are not adequately addressed by neither the public nor private economy.

It is important to understand that social economy enables market economy to become socially accountable, self-reliant, while remaining competitive, productive and profitable. The recent trend toward sustainable development and adoption of corporate social responsibility practices by different firms within different sectors speaks clearly about this effect. Reclaiming the market for collective ends and using reciprocity for the common good is definatelly a challenge for increasingly privatized and commercialized society. Since social economy assumes that organizations formulate new reciprocity-based solutions to individual and collective needs which results in humanizing effects on the operations of the market as a whole, social economy deserves to be elevated to a much more strategic and dominant position as a way of organizing our economic life.

\section{WHY IS HOMO ECONOMICUS AN AUTISTIC BEING?}

Man, "a weak animal, insufficient in himself, attains perfection only in civil society." Leonardo Bruni, in his introduction to the Italian translation of Aristotle's Politics.

Reductionist view of many economists is that humans are exclusively motivated by self-interest.
Focused around rational and narrowly selfinterested individual, the famous homo economicus concept is actually a poor representation of human behavior because interpersonal relations are neglected showing that the discipline still refuses to adopt a new scientific paradigm, the relational one. Assuming that the responsibility of each of us is to contribute to civil society, and to our collective well being, the quote above takes into consideration the relations between people, the well being of individuals and the public good as well. As it will be explained later in the text, such approach gives theoretical significance to our beliefs, ethics and values, which go well beyond any personal interest. If we consider the common saying, "Its just business," it is clear that we use this phrase when we are communicating a certain indifference or disregard towards interpersonal relationships. If a relationship is "just business," than the relationship is only the product of or means toward a certain "business" end.

By neglecting social dimension of economic behavior, we are both missing the person in relation to others, but also variety of social relations and reciprocity which frequently nurture social capital and re-distribute wealth better than the state or the marketplace. The examples are countless reciprocal acts going on in social networks, families and neighbourhoods, different communities and cities which are happening all the time.

According to Tzvetan Todorov (1998, p.23), the absence of social dimension in economics can be traced also in other fields of study because "studying the great currents of European philosophy as regards the definition of that which is human, one reaches an unexpected conclusion: the social dimension, the element of life in common, is not generally considered necessary for man." It is for this reason why for the most part of the last two centuries, the typical pillars of social economy - humanity, sociability, happiness - are almost totally absent. When explaining how the market works, with rare exceptions, economic science has been typically focused on economic agents and 'human propensity to truck, barter and exchange things" according to Adam Smith's writings. There is minimum or no need to bother with the category of person: the maximization of profit for the businessman and utility for the consumer is enough. This is quite paradoxical since this field of study has been focused essentially with the study of relations between men living in society. So the question is why throughout the last two centuries people constantly 
used Smith as a cornerstone of good economics, claiming the need for individual self-interest while neglecting the existence of broader, anthropological vision of human action and of society? Interestingly enough, a passage in Smith's Lectures at the University of Glasgow (1763) asserts that whenever commerce is introduced into a country, with it come also honesty and punctuality. Why only in very recent years, with writers such as Amartya Sen, Ken Arrow, Partha Dasgupta and others, the new understanding of Smith's thought has been revealed? Such an understanding underscores the importance of mutuality, trust and civic virtues.

Despite the open criticism of neoliberalism and the exsiting all-pervading economic perspective which still understands humans as informed, rational individuals and neglects the social dimension of economic behavior, we are still not considering the infinite purposes and means by which human beings in society may act together to achieve common ends. By thus, we are neglecting the benefits of social and solidarity economy where civic participation and reciprocity build on a civil welfare model providing services that foster human relationships and help sustainable development.

So why did it took so long to realize that homo economicus is an autistic being? Why is it difficult to understand that happiness is not based on pleasure but on relationship because"one cannot live a 'good life' unless with and thanks to others"? (Bruni 2012) How come has the oikos "the household," a site of deep relationships become so irrelevant in our oikonomia - "the rules of the household" - also known as economics?

Some of the most recent research in contemporary economics focuses around the importance of social bonds and civic ties which represents a shift from primacy of contracts and rights. Such renewed emphasis on the reciprocal bonds is a base for creating the economic model with 'free flow' of global capital and productive activities that benefit the many, and not the few. Only through civic participation and mutualism it is possible to bring together providers and beneficiaries, and to cut out 'the middle men,' which is the resource-consuming growing base of managemers, bureaucrats and gatekeepers whose task is to enforce centrally determined standards. As long as we remain within the realm of traditional economics focused on merely commercial attributes, instead of using market mechanisms to pursue explicit social objectives, it is very hard to talk about social innovation, social inclusion, economic justice and wellbeing in a proper and meaningful way. Since it alignes economic means to social ends, social economy becomes relevant as a sort of 'corrective' to the social and economic forces that continue to isolate economics from its social context.

\section{SOCIAL ECONOMY: HISTORY, MEANING AND PRINCIPLES}

Social economy is theoretical approach first developed by the 19th century French economic thinkers who distinguished social economy from political economy and applied economy, as the 'contribution of the economic sphere to social justice' (Moulaert and Ailenei, 2005, p.2040). However, the roots of social economy go back to the concept of the civil economy that was part of an Italian intellectual tradition that began in the 15th and 16th centuries as Civic Humanism and continued until the golden period of the Italian Enlightenment in the schools of Milan and Naples. It is interesting to mention here that the first Chair in Economics ever established in Europe was the Chair of Civil Economy at the University of Naples in 1753, held by Antonio Genovesi, the first great interpreter and theorist of the civil economy as a distinct field.

In most western economies, a range of names is interchangeably used to collectively describe the organisations and programs aiming to create social value in society. Although the term social economy usually coexists with other terms, such as the third sector, enterprises with social goals (Belgium), social cooperatives (Italy), cooperative enterprises serving the general interest (France), etc, for the purpose of this paper social economy is used because it represents the most useful and inclusive term referring to:

the production of goods and services not solely provided by the non-profit sector, but also, in some cases by private enterprises with shareholder agreements that force the majority of shareholders to agree to social objectives undertaken by the firm. Among the organisations that belong to the Social Economy, one can find associations cooperatives and mutual organisations and more recently foundations. This kind of economy is regulated by stakeholder principle, which stands in stark contrast with shareholder capitalism. The "Social Economy" is a broader concept than the non-profit sector. (OECD, 2003)

Recently, the term has gained attention in relation to welfare reform and the role of the non-profit sector in social and economic life (Evans and 
Syrett, 207; Kay, 2005). While existing definitions of social economy vary, the dominat conceptualisation of the term in the current social economy literature (Lyons, 2001; Haugh and Kitson, 2007) uses 'social economy' as a simile for the economic impact of the third sector - including nonprofits, cooperatives and mutuals which are present in many western democracies. Besides this wide conceptualization of the term, there is also a narrow application of the social economy language. It is more recent and it is used in policy discourses in Canada, and in academic studies in Europe (Evans and Syrett, 2007; Kay, 2005).

Narrow definition of social economy typically equates the social economy with "social enterprises" understood as revenue generating, non-profit activities that are meant to serve social or community purposes. Such organizations combine social with economic objectives and are formed by people to provide services for themselves or others, which is the product of mutuality or altruism. By some definitions, wherever people gather together to pursue economic activities with a view to meeting social as well as economic needs, you have elements of the social economy. Although typically the social economy represents economically large and a significant employer, there is a general lack of recognition of this important sector. Absence of complex regulatory policies and procedures that would fit the ways that social economy organizations operate represents the potential drag to the development of this important sector.

The key feature of social economy is reciprocity as an authentic economic principle that embodies social as opposed to merely commercial attributes. According to Nancy Neamtan (2005), social enterprise has a specific set of internal organizational properties because it ,aims to serve its members or the community, rather than simply striving for profit; is independent of the State; establishes a democratic decision-making process in its statutes and code of conduct, requiring that users and workers participate; prioritizes people and work over capital in the distribution of revenue and surplus; bases its activities on principles of participation, empowerment, and individual and collective responsibility." In his seminal book The Great Transformation from 1944, Karl Polany proposes an alternative economy, which is reembedded in politics and social relations. $\mathrm{He}$ points out the important anthropological insight stating that "human beings desire social recognition more than material wealth and that culture restricts commercial exchange: pace Adam Smith, "not the propensity to barter, but reciprocity in social behaviour dominates". As a result, the economic system should be a function of social organisation, not vice-versa." (Pabst, 2010).

\section{HAPPINESS-ECONOMY LINK}

"Happiness in the true sense is impossible for the individual to attain unless he seeks the happiness of the others".

Kenji Miyazawa (1896-1933)

According to Bruni and Zamagni (2007), the economy-happiness link is the key feature of the whole 18th century Italian tradition for ,there is no happines outside life in society and there is no society without intentional love for the public good." Despite the fact that public happiness was rooted in the concept of civil economy, representing an important feature of Genovesi's vision of economics and society in the first decades of 1700s, throughout the 19th and a good part of the 20th century people used Smith to claim the need for individual self-interest by thus neglecting his broader, anthropological vision of human action and of society. Although it is quite possible to be rich in solitude and without others, in order to be happy, it takes at least two (Bruni and Zamagni, 2007). According to Bruni (2004), due to the impact of the hedonist approach to economics and writings by J.S. Mill, Wicksteed and Pareto, ethical conception of happiness had been removed. Consequently, the methodological thinking shifted away from an emphasis on civil happiness after the Civil Humanism era so that the idea of public and relational happiness died out. This is mostly owed to misapprehension that all humans exist as rational beings that find happiness in maximizing their personal utility.

Although Smith clearly claims that self-interest is a powerful motive in human behaviour, it is by no means the only motive. The "official" theory of economic behaviour still focuses on extrinsic motivations only, being monetary or other, but always instrumental, that are added to intrinsic motivations which are considered irrelevant per se. For this reason, conventional economic theory restricts its field of study to extrinsic motivations alone, leaving it to psychology, philosophy,or sociology to study motivations. Only in recent years, with authors such as Ken Arrow, Partha Dasgupta, Amartya Sen, and others, have we come to a new understanding of Smith's thought. 
In Smith's less known work, Theory of Moral Sentiments, first published in 1759 but continually updated and republished until his death in 1790, it is possible to find that Smith clearly acknowledges that the most natural and human way of getting things from others is by mutuality, friendship and love (as in the family) and by thus points out the trait of human sociability and the fact that each of us has a need for something from others, and this need cannot be satisfied alone. This 'relational anthropology' basically means that relatonships wih others have to be seen as goods in themselves, not just as a means for acqiring material goods. For Bruni (2004), market relationality is defined by the exchange and the relationship, not just the exchange alone. In other words, market relationality means that each person needs others not only for provision of goods, but also for companionship and happiness as well.

When signing contracts and doing local or international business, people meet and recognize each other, and besides acquiring commodities, they also acquire personal well-being. Since happiness is the main determinant of human motivation, happiness rather than utility deserves to be the focus of an economic discourse. Unlike utility, which according to Pareto represents the property of the 'relation between a man and a thing,' happiness comes out of relationships between people. Therefore, mainstream economics has to embrace the new scientific paradigm, the relational one, because we cannot continue to isolate economics from its social context. It is a paradox that a field of study such as economics, which is by dealing with consumption choices, institutional structures, market exchanges or production of goods and services, basically concerned with relations between men living in society, for over two centuries neglects the category of person and excludes human sociability.

\section{SOCIAL ECONOMY PLAYING FIELD}

The organizational world today consists of three different sectors, each behaving according to a specific operational logic. In his book Social Enterprise in Anytown, John Pearce (2003) offers a clear description of the complex relationships between all 3 aspects or sectors of the economy and views them as systems (see Figure 1). According to Pearce (2003), each system is 'essentially about a different way of managing the economy, about a different mode of production". The private sector which John Pearce calls the first system, is profit-driven, seeking to maximise financial returns to individual owners. The second system, the domain of governments, is about redistribution and planning, while the third system is about citizens taking action to meet and satisfy needs themselves and working together in some collaborative way. It is basicaly derived from family and the household economy, but it extends do different ways people exchange with each other on voluntary basis (recreation, clubs, self-help groups, etc.). It also includes to a wide range of more formally structured organisations, some of which organise their affairs as charities (e.g. faithbased organisations, non-profits) or member-based associations (e.g. trade unions, service clubs), and others that explicitly pursue social goals using business means. The common feature is that the values of mutuality, self-help, caring for people and the environment are given higher priority than maximizing profits.

Although all three sectors of the market described above are distinct and operate on different economic principles, they are not hermetically sealed off from each other. There are numerous overlaps so that certain organizations operate at the boundaries of these distinctions. For example, universities and public/private partnerships might be placed at the borders of the public and private sectors. While some non-profit/private partnerships could be placed at the borders of the social economy and the private sector.

Millions of people around the globe practice social economy. Co-operatives, credit unions, mutuals, trade unions, business associations, non-profits, charities, volunteer organizations, cultural organizations, religious organizations, and recreational groups of all types and orientations are part of the social economy. What they all have in common is ,the promotion of mutual and collective benefit and the building of community that results from the operation of reciprocity either at the economic or social level" (Restakis, 2004). Since the "basic rule of the co-operative is contributive justice and reciprocity," (Bruni and Zamagni, 2007), the potential of cooperatives is in creation of satisfactory economic conditions for all people because they work and consume in order to produce for their own and other people's welfare, rather than for profit. This means "assuring individual and collective freedoms, protecting ecosystems as well as promoting sustainable development through abolishing all forms of exploitation, domination and exclusion, promotion of fair trade, ethical consumption, solidarity 
finance, and worker-managed productive enterprises" (Mance, 2007).

The challenge of social economy organisations is that they are not so easy on raising capital than investor-owned firms and correspondently they are slower in responding to expansionary opportunities that might emerge in a specific industry. For this reason, many cooperatives and mutuals find it easier to simply convert back to investor-owned firms. However, on the other side, the capital invested by social economy organisations in local communities is more securely rooted in such communities than investor-owned capital. In this context, in his essay Building Social Economy A. Pabst (2012) discusses the implications and possible effects of renewed emphasis on the principles of reciprocity and mutuality such as transforming welfare, social policy and reconnecting finance to the real economy concluding that ,instead of free-market fundamentalism or bureaucratic statism, it is the individual and corporate members of civil society who collectively determine the norms and institutions governing production and exchange." (Pabst, 2012).

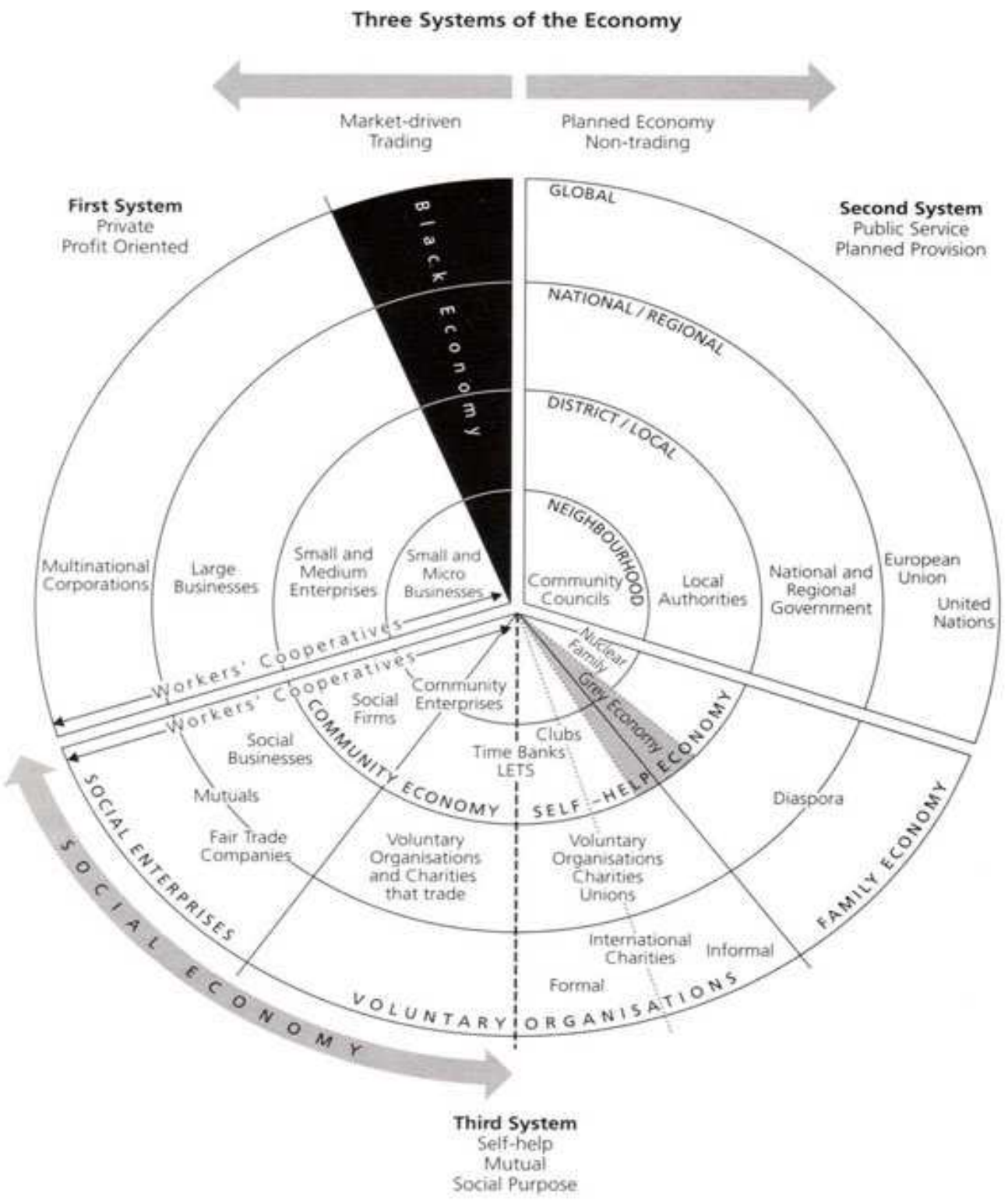

Figure 1: Pearce's depiction of the three economic systems and the social economy. (Source: http://www.socialeconomy-bcalberta.ca/social-economy/)

\section{CONCLUSION}

An approach based on relational anthropology and formation of markets that are accountable, self- regulating, profitable, humane, and competitive has the potential for rebuilding our economy and embedding welfare in communities (Bruyn, 2000). Drawing upon the ideas by Karl Polany and 
opposing the idea of the self-interested homo oeconomicus, this paper claims that humans are more relational, 'gift-exchanging animals' who are naturally disposed to cooperate for mutual benefit (Pabst, 2012). This is clearly shown in the groundbreaking book Civil Economy by Luigino Bruni and Stefano Zamagni (2007) where the authors point out that the concept of 'civil economy' shifts the primacy from rights and contracts to the social bonds and civic ties upon which vibrant democracies and market economies depend.

Some of the most innovative research in contemporary economics deals with the modern, liberal separation of private and public goods in favour of 'relational goods' and a renewed emphasis on the reciprocal bonds of sympathy that tie individuals together. Such research (Zamagni, 2011; Restakis, 2006, 2010; Pabst, 2010, 2012) generally points out the three key benefits of social economy: social innovation which is linking technological and organizational innovations to social initiatives, economic justice which is fostering sustainable development and promoting social solidarity and collective welfare which is about social inclusion and economic wellbeing through cooperative governance practices. Confirming the long documented evidence of the primacy of cooperation, the reported experiences on social economy in Australia (Barraket \& Crozier, 2005, Lyons 2001, 2003), Europe (Monzon, 2008, Evans, 2007), Brazil (Mance, 2007), together with 8000 cooperatives in the Italian region of Emilia Romana, one of the world's strongest cooperative economies, reflect ,the infinite purposes and means by which human beings in society act together to achieve common ends" (Pabst, 2012), and bring hope to those of us concerned about the degradation of natural care in our societies.

In the contemporary global environment where innovation, sustainability and entrepreneurship are becoming increasingly important organizational capabilities, cooperatives, and other forms of businesses where social relations are „mobilized for collective goals through the social control of capital" (Restakis, 2006) provide "a unique opportunity to chart an alternative to the complicit collusion of central states and free markets that characterise liberal political economy" (Pabst, 2012). Shifting the focus "from a self-interested pursuit of power or wealth (or both at once) to the quest for the common good" (Pabst, 2012), social economy organizations like social enterprises and co-operatives could, in the long run have humanizing effects on the operations of the market as a whole" (Restakis, 2010). In other words, since reciprocity creates and strengthens relationships and social networks, taking care of each other becomes central to society's well being. What raises hope in this sense, is the fact that there are millions of people taking part in social economy and sharing potential of collective approaches for sustainable living. At the same time, they are establishing connections and weaving collaborative networks which contribute to more justice, fairness, happiness and affirmation of new ways of producing, consuming and living in solidarity.

\section{REFERENCES}

BALTA. What is the Social Economy? Retrieved March 2013 from http://www.socialeconomybcalberta.ca/social-economy/

Barraket, J., \& Crozier, M. (2005). The social economy in Australia: A research agenda (an online article). Retrieved April 2013 http://www.tasa.org.au/uploads/2011/05/CrozierMichael-Session-16-PDF.pdf

Bruni, L. (2004). Civil Happiness: Economic and Human Flourishing in Historical Perspective. London: Routlege.

Bruni, L. (2012). The Wound and the Blessing: Economics, Relationships, and Happiness. New York: New City Press.

Bruni, L., \& Zamagni, S. (2007). Civil Economy: Efficiency, Equity, Public Happiness. Oxford: Peter Lang.

Bruyn, S. T. (2000). A Civil Economy: Transforming the Market in the 21st century (Evolvin Values for a Capitalist World). Ann Arbor, Michigan: University of Michigan Press.

Evans, M., \& Syrett, S. (2007). Generating Social Capital? The Social Economy and Local Economic Development. European Urban and Regional Studies, 14(1), 55-74.

Haugh, H., \& Kitson, M. (2007). The Third Way and the third sector: New Labour's economic policy and the social economy. Cambridge Journal of Economics, 31(6), 973-994.

Kay, A. (2005). Social capital, the social economy and community development. Community Development Journal, 41(2), 160-173.

Lyons, M. (2001). Third Sector: The contribution of nonprofit and cooperative enterprises in Australia. Crows Nest: Allen \& Unwin.

Lyons, M., \& Passey, A. (2003). The Economy: Time to Encourage the Third Sector (Australian Policy Online: Research and Evidence Base). Retrieved April 2013 http://apo.org.au/commentary/economytime-encourage-third-sector

Mance, E. A. (2007). Solidarity Economics. Turbulence. Retrieved from http://turbulence.org.uk/turbulence1/solidarity-economics/

Monzon, J. L., \& Chaves, R. (2008). The European 
Social Economy: Concept and Dimensions in the Third Sector. Annals of Public and Cooperative Economics, 79(3-4). Retrieved April 2013 from http://ideas.repec.org/a/bla/annpce/v79y2008i34p549-577.html

Moulaert, F., \& Ailenei, O. (2005). Social Economy, Third Sector and Solidarity Relations: A Conceptual Synthesis from History to Present. Urban Studies, 42(11), 2037-2053.

Neamtan, N. (2005). The Social Economy: finding a way between the market and the state. Policy Options, 26(6), 71-76.

The Non-Profit Sector in a Changing Economy. (2003). Retrieved March 2013, from OECD (Organisation for Economic Co-operation and Development) . from http://browse.oecdbookshop.org/oecd/pdfs/product/8 403021e.pdf

Pabst, A. (2010). A Paradoxical Politics: The Great Transofmration and the Future of Social Democracy. Policy Network Online. Retrieved March 2013 from http://www.policynetwork.net/pno_detail.aspx?ID=3 $867 \&$ title $=\mathrm{A}+$ paradoxical + politics $\% 3 \mathrm{a}+\mathrm{The}+$ Great +
Transformation+and+the+future+of+social+democr acy

Pabst, A. (2012). Building a Civil Economy. Our Kingdom: Power \& Liberty in Britain. Retrieved April 2013 from http://www.opendemocracy.net/ourkingdom/adrianpabst/building-civil-economy-0

Pearce, J. (2003). Social Enterprise in Anytown. London: Calouste Gulbenkian Foundation!

Restakis, J. (2006). Defining the Social Economy - The BC Context (an online article). Retrieved April, 2013 from http://www.uvic.ca/research/centres/cccbe/assets/do cs/publications/practitioner/Restakis_DefiningSocial Economy.pdf

Restakis, J. (2010). Humanizing Economy: Cooperatives in the Age of Capital. Gabriola Island, Canada: New Society Publishers.

Todorov, T. (1998). Les abus de la mémoire. Paris: Arléa.

Zamagni, S., \& Zamagni, V. (2011). Cooperative Enterprise: Facing the Challenge of Globalization. Cheltenham: Eward Elgar Pub. 